\title{
Acute actions of insulin-like growth factor II on glucose metabolism in adult rats
}

\author{
F. Stiimpel and H. Hartmann \\ Department of Medicine, Division of Gastroenterology and Endocrinology, Georg-August-Universität, Göttingen, FRG
}

\begin{abstract}
Summary. The metabolic potency of recombinant human insulin-like growth factor II was studied in anaesthetized adult rats by obtaining dose-response curves for the hypoglycaemic action and for the stimulation of glucose metabolism during euglycaemic clamping. Compared to insulin, about 50 times higher doses of insulin-like growth factor II were required to result in identical in vivoresponses, with half-maximally effective serum concentrations for the stimulation of glucose disposal during clamp studies of about 0.8 and $50 \mathrm{pmol} / \mathrm{ml}$, respectively. A similar difference in potency was observed for the dose-dependent stimulatory actions on glucose metabolism in individual target tissues. Half-maximally effective
\end{abstract}

serum concentrations in the range of 0.8 to $3.0 \mathrm{pmol} / \mathrm{ml}$ for insulin and of 40 to $70 \mathrm{pmol} / \mathrm{ml}$ for insulin-like growth factor II were seen to be required for 2-deoxyglucose uptake, glycogen formation in skeletal muscle and lipogenesis in epididymal fat. Maximal responses were identical with both peptides. These data suggest that in vivo acute metabolic actions of insulin-like growth factor II on carbohydrate metabolism occurred through insulin receptors.

Key words: Insulin-like growth factor II, insulin action, euglycaemic clamping, glucose metabolism, lipogenesis, glycogenesis.
Insulin-like growth factor II (IGF-II) is a polypeptide hormone structurally related to proinsulin and insulin-like growth factor I (IGF-I) [1,2]. Whereas IGF-I (also previously named somatomedin $C$ ) has been shown to mediate most of the action of growth hormone on target tissues [3], the physiological role of IGF-II, particularly in humans, remains less well understood. In the rat, IGF-II is regarded as a fetal growth factor, while post-natally, plasma IGF-II levels decrease and tissue IGF-II mRNA expression apparently ceases $[4,5]$. Recently, direct evidence for a physiological role of IGF-II in rodent embryonic growth was provided by studies where the IGF-II gene was disrupted by gene targetting [6]. Conversely, in man low IGF-II concentrations have been reported for fetal blood compared to adult human plasma [7].

Acute metabolic actions - qualitatively resembling those of insulin - have been reported for IGF-II from in vivo and in vitro studies [8-10]. When injected into normal and hypophysectomized rats IGF-II was shown to lower blood glucose and to stimulate tissue glycogen and lipid synthesis in the presence of an anti-insulin serum [10]. In addition, a recent study performed in fasted lambs, suggested a slight stimulatory action of IGF-II on glucose clearance [11]. In man, indirect evidence for acute effects of IGF-II on glucose metabolism is provided by investiga- tions reported from patients with non-islet-cell tumourassociated hypoglycaemia [12-15]. Furthermore, various in vitro studies, including work with human adipocytes, demonstrated insulin-like metabolic effects of IGF-II [16]. Several lines of evidence suggest that these metabolic actions of IGF-II were not mediated through IGF-II receptors but through insulin receptors, to which IGF-II can bind with low affinity [17-19].

For further characterization of acute actions of IGF-II on glucose metabolism dose-response curves were obtained in the present investigation to determine the hypoglycaemic potency following i. v. bolus injection and the stimulatory action on glucose disposal utilising the euglycaemic clamp technique in anaesthetized rats. In addition, while using labelled tracers such as $\left[{ }^{14} \mathrm{C}\right]$ glucose and $2-\left[{ }^{3} \mathrm{H}\right]$ deoxyglucose during clamping, IGF-II action on individual tissues and on different metabolic pathways, e.g. glycogen synthesis and lipogenesis, was studied.

\section{Materials and methods}

\section{Materials}

Chemicals were reagent grade and obtained from commercial sources. Enzymes were purchased from Boehringer Mannheim (Mannheim, FRG) and porcine insulin was from Serva (Heidelberg, FRG); 
Table 1. Time course of free and total serum insulin-like growth factor II concentrations during euglycaemic clamp studies

\begin{tabular}{llrrr}
\hline $\begin{array}{l}\text { IGF-II infusion } \\
\left(\mathrm{nmol} \cdot \mathrm{kg}^{-1} \cdot \mathrm{h}^{-1}\right)\end{array}$ & \multicolumn{4}{l}{ IGF-II concentration (pmol/ml) } \\
\cline { 2 - 5 } & $\begin{array}{l}\text { Time } \\
\text { (min) }\end{array}$ & & 90 & 120 \\
\hline IGF-II (50) & Total & $22.0 \pm 3.4$ & $53.8 \pm 4.7$ & $47.3 \pm 8.2$ \\
& Free & $1.9 \pm 0.4$ & $34.1 \pm 9.6$ & $24.8 \pm 6.4$ \\
IGF-II (170) & Total & $26.3 \pm 2.9$ & $179.3 \pm 24.3$ & $197.3 \pm 36.8$ \\
& Free & $1.85 \pm 0.7$ & $172.1 \pm 42.4$ & $167.0 \pm 16.9$ \\
\hline
\end{tabular}

Data are means \pm SD of at least seven experiments at each infusion rate

recombinant human IGF-II was a gift from Ciba Geigy (Basel, Switzerland). 2-Deoxy-(1-3H)-D-glucose (specific activity of $-14 \mathrm{Ci} / \mathrm{mmol}$ ) was obtained from Amersham-Buchler (Braunschweig, $\mathrm{FRG}$ ) and ( $\mathrm{U}-{ }^{14} \mathrm{C}$ )-D-glucose (specific activity $\sim 4 \mathrm{mCi} / \mathrm{mmol}$ ) from New England Nuclear (Dreieich, FRG). Insulin radioimmunoassay kit was purchased from Pharmacia (Ratingen, FRG). The anti-IGF-II serum for radioimmunological determination of IGF-II was a gift from Prof. J. Zapf, Zürich, Switzerland.

\section{Animals}

Male Wistar rats (220-290 g body weight) were obtained from Mus Rattus (Brunnthal, FRG). They were kept on a $12 \mathrm{~h}$ light/dark cycle with free access to a standard diet (Altromin 1324; Altromin, Lage, FRG).

\section{Hypoglycaemic action}

Experiments were started at 14.00 hours; food was removed $8 \mathrm{~h}$ before to assure absence of ingested nutrients in the intestine and to achieve a similar hepatic glycogen content. Anaesthesia was obtained by intraperitoneal injection of pentobarbital $(60 \mathrm{mg} / \mathrm{kg}$ ). Animals were kept on heated pads to maintain body temperature throughout the experiments. After preparation of the right jugular vein a polyvinylchloride catheter (external diameter $\sim 0.8 \mathrm{~mm}$ ), obtained from Mahrt und Hoerning (Göttingen, FRG), was inserted and positioned in the right atrium for injection of hormones and blood sampling. Following an equilibration period of $20 \mathrm{~min}$ with repeated three-fold determinations of blood glucose (samples of $50 \mu \mathrm{l}$ at $10-\mathrm{min}$ intervals), an i.v. bolus of insulin or IGF-II was administered in a volume of $250 \mu \mathrm{l}-0.5,2.0,4.0,8.0$ and $12.0 \mathrm{nmol} \cdot \mathrm{kg}^{-1}$ of insulin or $25,50,100,200$ and $400 \mathrm{nmol} \cdot \mathrm{kg}^{-1}$ body weight of IGF.II in $0.9 \%$ weight/volume (w/v) sodium chloride $(\mathrm{NaCl})$ solution containing $0.3 \%(\mathrm{w} / \mathrm{v})$ bovine serum albumin (BSA). For determination of blood glucose subsequent blood samples $(50 \mu \mathrm{l})$ were collected at 10 -min intervals, deproteinized in $500 \mu \mathrm{l}$ perchloric acid $(0.33 \mathrm{~mol} / \mathrm{h})$ and analysed for glucose content by the glucose-dehydrogenase method as described [20]. Hypoglycaemia was quantitated by calculating the area over the blood glucose concentration curve for individual experiments by the trapezoid method [21]. The basal line was given by the mean of the three values prior to hormone injection.

\section{Euglycaemic clamp studies}

Animals were fasted for $24 \mathrm{~h}$, anaesthetized and kept during the experiment as described above. In addition to the venous catheter an arterial cannula was inserted into the right carotid artery. According to the method of DeFronzo et al. [22] euglycaemic clamp studies were performed by continous venous hormone infusion $\left(1.2 \mathrm{ml} \cdot \mathrm{h}^{-1}\right.$, Unita $1 \mathrm{~b}$; Braun, Melsungen, FRG) of insulin $(0.5,1.0,2.0,4.0,8.0$,
10.0 and $\left.13.0 \mathrm{nmol} \cdot \mathrm{kg}^{-1} \cdot \mathrm{h}^{-1}\right)$ or IGF-II $(25,50,100,170$ and $\left.300 \mathrm{nmol} \cdot \mathrm{kg}^{-1} \cdot \mathrm{h}^{-1}\right)$ dissolved in $0.9 \%(\mathrm{w} / \mathrm{v}) \mathrm{NaCl}$ solution containing $0.3 \% \mathrm{BSA}$. A priming IGF-II bolus (one-third of the respective dose per hour) was given. Euglycaemia was maintained by infusing a solution of exogenous glucose ( 0 to $1.5 \mathrm{ml} \cdot \mathrm{h}^{-1}$, glucose concentration ranging from 50 to $220 \mathrm{mg} / \mathrm{ml}$ ) using a variable infusion pump (Wissenschaftliche Werkstätten; Universität Göttingen, FRG). Repeated measurements of arterial blood glucose concentrations (samples of $10 \mu \mathrm{l}$ serum obtained at 10 - to 20 -min intervals, Beckman Glucose Analyzer II; Beckman, München, FRG) were performed to guide the adjustment of the glucose infusion rate in accordance with short-term changes of glucose concentration. The glucose infusion rate during the last $30 \mathrm{~min}$ of the 2 -h clamp experiment was used as a measure of insulin or IGF-II action on whole body glucose disposal. Blood samples $(200 \mu \mathrm{l})$ for determination of insulin or IGF-II were taken at 0,90 and 120 min.

\section{Effects on individual tissues}

Insulin and IGF-II action on glucose uptake in individual tissues during euglycaemic clamping were estimated by the use of labelled 2-deoxyglucose as described by Kraegen et al. [23]. In brief, animals received an i.v. bolus injection of 2 -deoxy-D- $\left(1-{ }^{3} \mathrm{H}\right)$-glucose $(50 \mu \mathrm{Ci}$ in a volume of $300 \mu \mathrm{l} 0.9 \%[\mathrm{w} / \mathrm{v}] \mathrm{NaCl}$ solution) at $60 \mathrm{~min}$ after the commencement of the glucose clamp followed by subsequent arterial blood sampling for determination of glucose and 2-deoxyglucose concentrations. At the completion of the clamp (at $120 \mathrm{~min}$ ) tissue samples were taken from diaphragm, white and red parts of the gastrocnemius muscle, heart and epididymal fat to be analysed for tissue accumulation of 2-deoxyglucose. Analysis and caiculation of glucose metabolic index $\mathrm{Rg}^{\prime}$ were performed as described in detail elsewhere [24].

Incorporation of labelled glucose into lipids of epididymal fat pads and into tissue glycogen stimulated by insulin or IGF-II was determined in separate experiments following an $i$. v. bolus injection of $\left(\mathrm{U}_{-}{ }^{24} \mathrm{C}\right.$ )-glucose (in $250 \mu \mathrm{l} 0.9 \%[\mathrm{w} / \mathrm{v}] \mathrm{NaCl}$ solution) at $60 \mathrm{~min}$ during euglycaemic clamping with tissue sampling at $120 \mathrm{~min}$ as described by Zapf et al. [10]. Extraction of lipids from epididymal fat was performed according to Stansbie et al. [25]. Lipogenesis was estimated by dividing radioactivity incorporated into lipids by the area under the blood radioactivity time curve following bolus injection. Glycogen formation was studied by analysing individual tissues for radioactivity incorporated into glycogen as described [10]. Tissue glycogen content was determined enzymatically [26]. Glycogenesis was estimated by dividing radioactivity incorporated into tissue glycogen by tissue glycogen content with correction for serum radioactivity following bolus injection of labelled glucose.

\section{Analytical methods}

Radioactivity in aqueous samples was counted in $10 \mathrm{ml}$ Hydroluma scintillant (Baker, Deventer, The Netherlands) in a beta-counter (Mark III; Searle, Des Plaines, Ill., USA); lipids were counted using $10 \mathrm{ml}$ Instant Szint. Gel II (Canberra Packard, Zürich, Switzerland). Serum hormone samples obtained at steady-state conditions during clamp experiments were measured in duplicate. Insulin concentrations were determined by a commercial radioimmunoassay (radioactivity was counted with a Gamma-Master 1277; Ratingen, FRG). For the measurement of total IGF-II concentrations $1 \mathrm{ml}$ of $0.5 \mathrm{~mol} / 1 \mathrm{HCl}$ was added to $100 \mu \mathrm{l}$ serum and applied to Sep-Pak $\mathrm{C}_{18}$-cartridges (Waters Associates, Milford, Mass., USA). IGF-II was eluted with methanol, lyophilized and dissolved in $1 \mathrm{ml}$ of assay buffer (phosphate-buffered saline pH 7.4 with $0.2 \%$ [w/v] human serum albumin). Free IGF-II was separated from protein bound on a Sephadex G 50 column $(1 \times 100 \mathrm{~cm}$, flow rate $12 \mathrm{ml} / \mathrm{h})$ in serum samples of $300 \mu \mathrm{l}$ under neutral conditions $\left(0.15 \mathrm{~mol} / / \mathrm{NH}_{4} \mathrm{HCO}_{3}\right.$ buffer, $\mathrm{pH}$ 7.7) as described in detail elsewhere [10], lyophilized and 


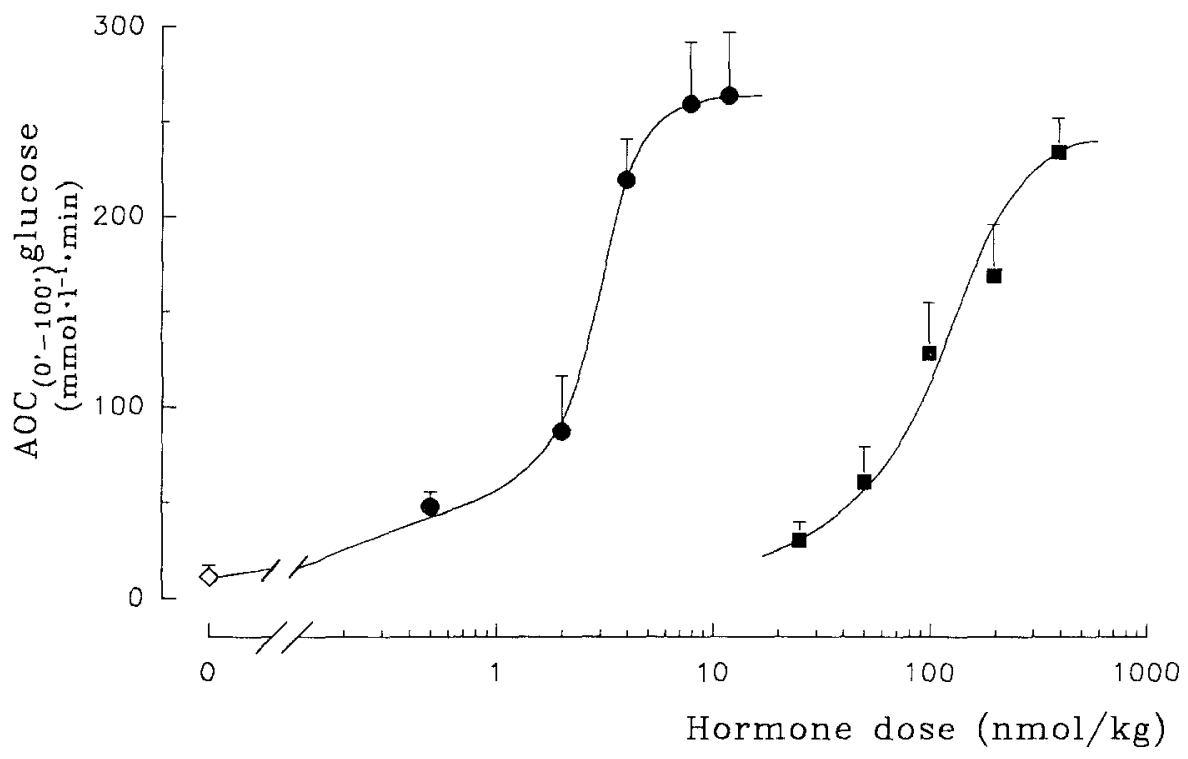

Fig. 1. Hypoglycaemic potency, Anaesthetized rats received i.v. bolus injections of insulin (-) or IGF-II ( $-\mathbf{m})$. Hypoglycaemia was quantitated by integrating the area over the curve (AOC) of blood glucose decrease for $100 \mathrm{~min}$ following the hormone injection. Control animals $(\diamond)$ received an identical volume of sodium chloride solution. Values are means \pm SD of at least five experiments each at individual doses dissolved in $1 \mathrm{ml}$ of assay buffer. After appropriate dilution $100 \mu \mathrm{l}$ each were assayed radioimmunologically using a specific rabbit antibody.

\section{Results}

\section{Hypoglycaemic potency}

Following an i.v. bolus a dose-dependent decrease of blood glucose concentration was observed with insulin and IGF-II. At the highest doses glucose nadirs in the range of 1.94-2.22 mmol/l were observed; death from hypoglycaemia did not occur. Figure 1 demonstrates the hypoglycaemic potency calculated by integrating the area over the curve (AOC) for blood glucose decrease. Compared to insulin the potency of IGF-II at a half-maximally effective dose was about $2 \%$, e.g. $\sim 2 \mathrm{nmol} / \mathrm{kg}$ for insulin and $\sim 100 \mathrm{nmol} / \mathrm{kg}$ for IGF-II, whereas identical maximal hypoglycaemic effects were observed with both peptides. Saline-injected control animals did not show significant changes in blood glucose concentrations.

\section{Euglycaemic clamp studies}

Figure $2 \mathrm{a}$ depicts the stimulatory action of insulin and IGF-II on whole body glucose disposal. A dose-dependent increase was observed for both peptides with an identical maximal stimulation of $\sim 19.0 \mathrm{mg} \cdot \mathrm{kg}^{-1} \cdot \mathrm{h}^{-1}$. However, an approximately 30 -fold higher dose of IGF-II was required to achieve similar rates of glucose disposal with half-maximally effective doses of $\sim 1.0 \mathrm{nmol} \cdot \mathrm{kg}^{-1} \cdot \mathrm{h}^{-1}$ for insulin and of $\sim 50.0 \mathrm{nmol} \cdot \mathrm{kg}^{-1} \cdot \mathrm{h}^{-1}$ for IGF-II, respectively. Half-maximally effective serum concentrations of insulin and IGF-II (measured in samples obtained at steady-state conditions during clamping) were in the range of $0.8 \mathrm{pmol} / 1$ for insulin and $50 \mathrm{pmol} / \mathrm{ml}$ for IGF-II (Fig. 2b). The time course for serum concentrations of the free and total portion of IGF-II is given in Table 1. Sodium chloride infused control animals did not require exogeneous glucose.

Stimulation of 2-deoxyglucose uptake in individual tissues

For insulin- and IGF-II-treated rats maximal stimulation of 2-deoxyglucose uptake was identical in several target tissues. The uptake was dose-dependent as demonstrated in Figure 3 for skeletal muscle and diaphragm. Half-maximally effective serum concentrations however, were considerably higher in IGF-II-infused animals (see Fig. 3 and Table 2 for individual tissues). The respective serum concentrations were in the range of 0.8 to $0.3 \mathrm{pmol} / \mathrm{ml}$ for insulin and 40 to $70 \mathrm{pmol} / \mathrm{ml}$ for IGF-II.

\section{Stimulation of lipogenesis in epididymal fat pads}

Half-maximally effective serum concentrations of insulin and IGF-II for the stimulation of lipogenesis are given in Table 2. The effects of both peptides were dose-dependent with similar maximal stimulatory actions.

\section{Stimulation of glycogenesis}

Incorporation of labelled glucose into tissue glycogen was stimulated by insulin and IGF-II demonstrating a similar difference in potency as for the metabolic actions described above. At infusion rates of insulin and IGF-II that resulted in almost identical stimulation of total body glucose disposal during euglycaemic clamping (infusion rates of 2.0 and $100 \mathrm{nmol} \cdot \mathrm{kg}^{-1} \cdot \mathrm{h}^{-1}$ ) glycogenesis in red and white skeletal muscle was stimulated to a similar extent (Fig. 4). 

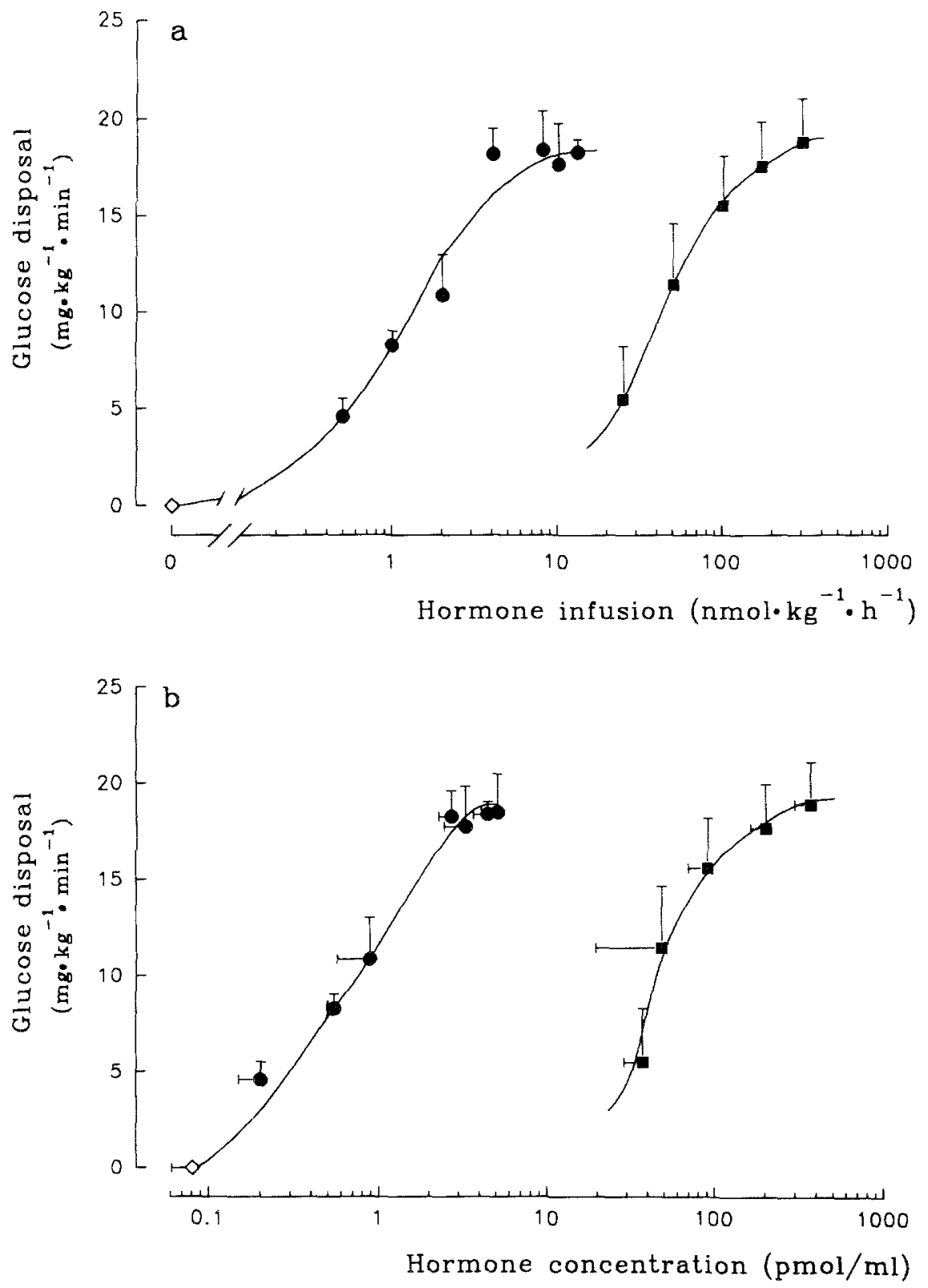

Fig. 2 a,b. Stimulation of whole body glucose disposal during euglycaemic clamping. Anaesthetized rats received $i . v$. infusions of insulin $(-)$ ) or IGF-II (-m). Exogenous glucose was infused to maintain euglycaemia. The amount of glucose infused at steady-state conditions $(90-120 \mathrm{~min}$ after commencement) is equivalent to whole body glucose utilisation. a Hormone infusion rates. b Arterial hormone concentrations at steady-state. Control animals $(\diamond)$ received identical volumes of sodium chloride solution. Values are means $\pm \mathrm{SD}$ of at least five experiments each at individual doses

\section{Discussion}

In the present study acute actions of IGF-II were observed in vivo, qualitatively resembling those of insulin but with a considerably lower potency for IGF-II of approximately $2 \%$ that of insulin. IGF-II-induced hypoglycaemia has been described previously in experimental animals; however, an estimation of its potency compared to insulin, e.g. by obtaining respective dose-response curves, was hampered by the limited availability of serum-derived IGF-II $[8,10]$. Furthermore, these early observations suggested that only free IGF-II, but not the IGF carrier protein complex, was available to insulin target tissues [10]. The present results obtained with recombinant human IGF-II using the euglycaemic clamp provide further evidence that free IGF-II would be required for acute metabolic effects, since a stimulatory action of IGF-II on total body glucose disposal and on glucose metabolism in individual tissues was observed only when serum concentrations of free IGF-II were raised substantially. Since the observed half-maximally effective serum IGF-II concentrations exceeded the reported affinity of IGF-II for the IGF-II receptor several times [18], the present data are in line with the assumption that acute metabolic actions of IGF-II were mediated through insulin receptors [17]. Thus, the present data obtained in vivo support conclusions derived from previous in vitro studies [19]. It is of interest to note that in a recent investigation comparing the acute effects of recombinant human IGF-I and IGF-II on glucose metabolism in fasted lambs, a lower potency of IGF-II was reported, i.e. an identical infusion of both peptides resulted in a considerably smaller increase of glucose clearance in IGF-II treated animals [11]. These latter data do not agree with previous results obtained with IGF-I in anaesthetized rats suggesting a potency of IGF-I on glucose metabolism almost identical to that observed in the present 

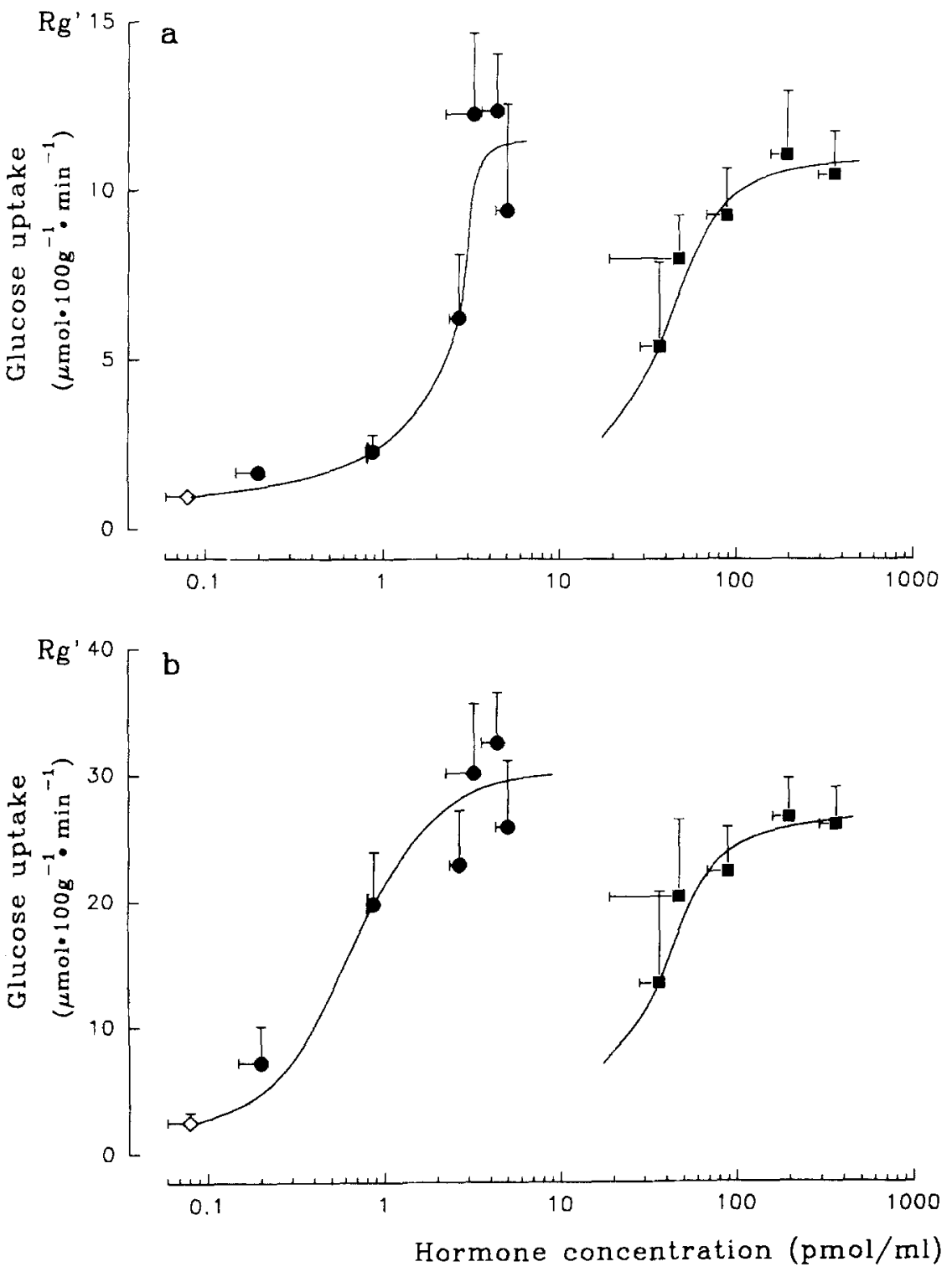

Fig. 3a,b. Stimulation of 2-deoxyglucose uptake in red parts of gastrocnemic muscle (a) and diaphragm (b) by insulin and IGF-II. Anaesthetized rats received $i . v$. infusions of insulin $(-)$ ) or IGF-II $(-\mathbf{m})$ as depicted in Figure 2. At 60 min after commencement of the euglycaemic clamp an i. v. bolus of labelled 2-deoxyglucose was given followed by tissue sampling at $120 \mathrm{~min}$. Measurement of radioactivity and calculation of glucose metabolic index $\left(\mathrm{Rg}^{\prime}\right)$ were performed as described in Methods. Hormone concentrations were measured in arterial blood samples obtained at steady-state conditions during clamping (means of values measured at 90 and 120 min after commencement of hormone infusion). Control animals $(\diamond)$ received sodium chloride infusions. Values are means \pm SD of at least five experiments each at individual doses

study with IGF-II [27]. Since neither IGF-II serum concentrations nor dose-response curves were reported for the studies in lambs, there is little evidence for a different stimulatory potency of IGF-II compared to IGF-I on glucose metabolism. However, since experimental animals were fasted for a prolonged period, fasting-related changes of IGF binding proteins resulting in a reduced potency of IGF-II remain possible. As to the role of IGF-I and IGF-II in short-term regulation of protein metabolism, little information regarding IGF-II is available at present. For IGF-I, a more sensitive regulatory response of protein metabolism compared to carbohydrate metabolism has been claimed [11].

Using isotopic tracer methodology the effects of IGFII on individual tissues were studied in the present work. Tissue glucose uptake, assessed with 2-deoxyglucose, as well as the stimulation of lipogenesis and glycogenesis were affected in a variety of tissues with a similar difference in potency for IGF-II and insulin as that observed for the respective effects on total body glucose metabo- lism. Thus, a preferential action of IGF-II on glucose metabolism of an individual tissue appears unlikely.

The data derived from the present study do not suggest a physiological role of IGF-II in the regulation of carbohydrate metabolism in adults. Given the rather weak "somatomedin-like" activity of IGF-II compared to IGF-I [28] and the apparent non-dependence of circulating IGF-II concentrations from growth hormone [29], the physiologi-

Table 2. Stimulation of 2-deoxyglucose uptake and lipogenesis in epididymal fat pads by insulin and insulin-like growth factor II

\begin{tabular}{lll}
\hline & \multicolumn{2}{l}{$\begin{array}{l}\text { Half-maximally effective serum } \\
\text { concentration (pmol/mI) }\end{array}$} \\
\cline { 2 - 3 } & Insulin & IGF-II \\
\hline 2-deoxyglucose uptake & 1.5 & 50 \\
Lipogenesis & 2.0 & 70 \\
\hline \multirow{2}{*}{$\begin{array}{l}\text { a Data are derived graphically from individual dose-response curves } \\
\text { with at least four experiments at each individual dose }\end{array}$}
\end{tabular}




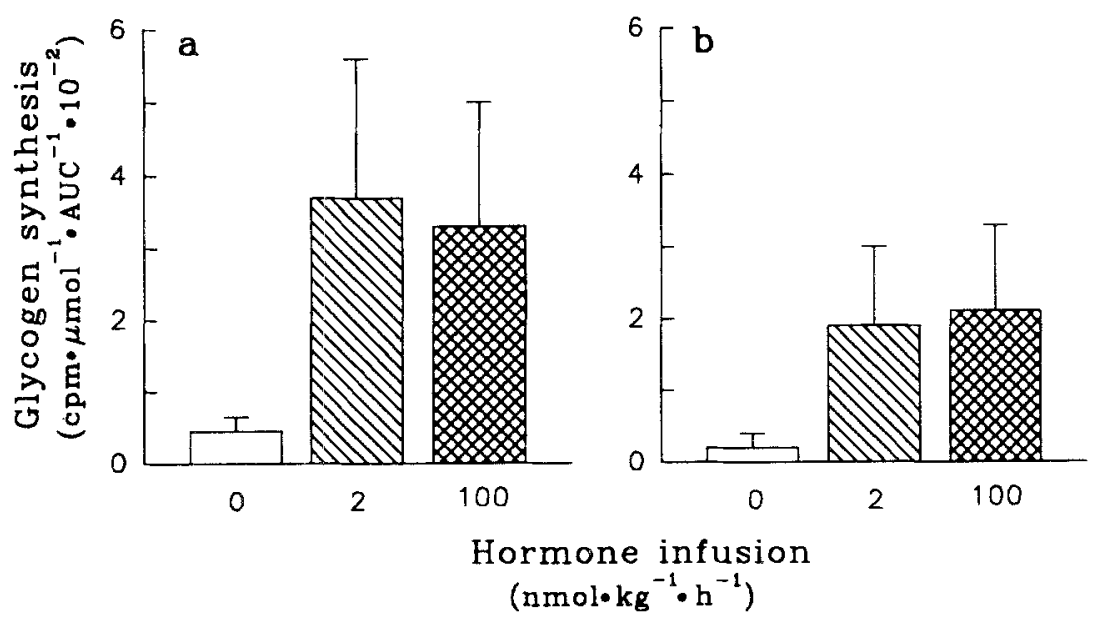

Fig. 4 a,b. Stimulation of glycogen formation in red (a) and white (b) parts of gastrocnemic muscle during euglycaemic clamping. Animals received i. v. infusions of $2.0 \mathrm{nmol} \cdot \mathrm{kg}^{-1} \cdot \mathrm{h}^{-1}$ insulin $(\otimes)$ and $100 \mathrm{nmol} \cdot \mathrm{kg}^{-1} \cdot \mathrm{h}^{-1}$ IGF-II ( $)$. Glycogen synthesis was measured with (U. $\left.{ }^{14} \mathrm{C}\right)$-glucose as described in Methods. Control animals $(\square)$ received sodium chloride solution. Values are means \pm SD of at least four experiments at each dose

cal function of circulating IGF-II in adulthood can hardly be explained by current knowledge. However, caution should be taken in extrapolating the present data for IGFII obtained in adult rat towards human physiology in view of the different developmental pattern, i.e. very low serum IGF-II levels in adult rats [30] compared to rather high levels in adult humans [7]. Furthermore, species differences in IGF binding proteins have been noted that could influence biological actions of IGF-II [31].

Recent in vitro studies have reported an IGF-IIdependent modulation of the endocytosis of mannose 6-phosphate containing ligands, e.g. lysosomal enzymes, thereby potentially regulating their extracellular concentrations [19]. However, the recognition of the biological relevance of IGF-II in human adults will depend on future studies.

Acknowledgements. We are grateful to Ms. S. Buß for excellent technical assistance and to Dr. F. Schmitz for valuable advice regarding the IGF radioimmunoassay. This work was supported by grant Stu 172/1-1 from the Deutsche Forschungsgemeinschaft; Bonn-Bad Godesberg, FRG.

\section{References}

1. Froesch ER, Zapf J (1985) Insulin-like growth factors and insulin: comparative aspects. Diabetologia 28: 458-493

2. Humbel RE (1990) Insulin-like growth factors I and II. Eur J Biochem 190: 445-462

3. Schoenle E, Zapf J, Humbel RE, Froesch ER (1982) Insulin-like growth factor I stimulates growth in hypophysectomized rats. Nature 296: 252-253

4. Adams SO, Nissley SP, Handwerger S, Rechler MM (1983) Developmental patterns of insulin-like growth factor-I and -II synthesis and regulation in rat fibroblasts. Nature 302: 1.50-153

5. Brown AL, Graham DL, Nissley SP, Hill DJ, Strains AS, Rechler MM(1986) Developmental regulation of insulin-like growth factor II mRNA in different rat tissues. J Biol Chem 261: 13144 13150

6. DeChiara TM, Efstratiadis A, Robertson EJ (1990) A growthdeficiency phenotype in heterozygous mice carrying an insulinlike growth factor II gene disrupted by targeting. Nature 345: 7880

7. Ashton IK, Zapf J, Einschenk I, MacKenzie IZ (1985) Insulinlike growth factors (IGF) 1 and 2 in human foetal plasma and re- lationship to gestational age and foetal size during midpregnancy. Acta Endocrinol 110: 558-563

8. Froesch ER, Müller WA, Bürgi H, Waldvogel M, Labhart A (1966) Nonsuppressible insulin-like activity of human serum. II: biological properties of plasma extracts with nonsuppressible insulin-like activity. Biochem Biophys Acta 121:360-374

9. Zapf J, Schoenle E, Froesch ER (1978) Insulin-like growth factors I and II: some biological actions and receptor binding characteristics of two purified constituents of nonsuppressible insulin-like activity of human serum. Eur J Biochem 87: 285-296

10. Zapf J, Hauri C, Waldvogel M, Froesch ER (1986) Acute metabolic effects and half-lives of intravenously administered insulinlike growth factors I and II in normal and hypophysectomized rats. J Clin Invest 77: 1768-1775

11. Douglas RG, Gluckman PD, Ball K, Breier B, Shaw JHF (1991) The effects of infusion of insulinlike growth factor (IGF) I, IGFII, and insulin on glucose and protein metabolism in fasted lambs. J Clin Invest 88: 614-622

12. Hyodo T, Megyesi K, Kahn CR, McLean JP, Friesen HG (1977) Adrenocortical carcinoma and hypoglycemia: evidence for production of nonsuppressible insulin-like activity by the tumor. J Clin Endocrinol Metab 44: 1175-1184

13. Daughaday WH, Trivedi B, Kapadia M (1981) Measurement of insulin-like growth factor II by a specific radioreceptor assay in serum of normal individuals, patients with abnormal growth hormone secretion, and patients with tumor-associated hypoglycaemia. J Clin Endocrinol Metab 53: 289-294

14. Daughaday WH, Emanuele MA, Brooks MH, Barbato AL, Kapadia M, Rotwein P (1988) Insulin-like growth factor-II synthesis and secretion by a leiomyosarcoma with associated hypoglycaemia. N Engl J Med 319: 1434-1440

15. Shapiro ET, Bell GI, Polonsky KS, Rubenstein AH, Kew MC, Tager HS (1990) Tumor hypoglycaemia: relationship to high molecular weight insulin-like growth factor-II. J Clin Invest 85 : 1672-1679

16. Sinha MK, Buchanan C, Rainero-Maldonado C et al. (1990) IGF-II receptors and IGF-II-stimulated glucose transport in human fat cells. Am J Physiol 258: E534-E542

17. Czech MP (1989) Signal transmission by the insulin-like growth factors. Cell 59: 235-238

18. Rechler MM, Nissley SP (1985) The nature and regulation of the receptors for insulin-like growth factors. Ann Rev Physiol 47: $425-442$

19. Hartmann H, Meyer-Alber A, Braulke T (1992) Metabolic actions of insulin-like growth factor II in cultured adult rat hepatocytes are not mediated through the insulin-like growth factor II receptor. Diabetologia 35: 216-223

20. Vormbrock R (1974) UV-method with glucose dehydrogenase. In: Bergmeyer HU (ed) Methods of enzymatic analysis, Vol 6. Verlag Chemie, Weinheim, pp 172-178 
21. Yeh KC, Kwan KC (1978) A comparison of numerical integrating algorithms by trapezoidal, Lagrange, and spline approximation. J Pharmacokin Biopharm 6: 79-93

22. DeFronzo RA, Tobin JD, Andres R (1979) Glucose clamp technique: a method for quantifying insulin secretion and resistance. Am J Physiol 237: E214-E223

23. Kraegen EW, James DE, Jenkins AB, Chisholm DJ (1985) Doseresponse curves for in vivo insulin sensitivity in individual tissues in rats. Am J Physiol 248: E353-E362

24. Kraegen EW, James DE, Storlien LH, Burleigh KM, Chisholm DJ (1986) In vivo insulin resistance in individual peripheral tissues of the high fat fed rat: assessment by euglycaemic clamp plus deoxyglucose administration. Diabetologia 29: 192-198

25. Stansbie D, Brownsey RW, Crettaz M, Denton RM (1976) Acute effects in vivo of anti-insulin serum on rates of fatty acid synthesis and activities of acetyl-coenzyme A carboxylase and pyruvate dehydrogenase in liver and adipose tissue of fed rats. Biochem $\mathbf{J}$ 160: 413-416

26. Keppler D, Decker K (1983) Glycogen. In: Bergmeyer HL, Bergmeyer J, Grassl M (eds) Methods of enzymatic analysis, Vol 6. Verlag Chemie, Weinheim, pp 11-18

27. Schmitz F, Hartmann H, Stümpe1 F, Creutzfeldt W (1991) In vivo metabolic action of insulin-like growth factor I in adult rats. Diabetologia 34: 144-149

28. Schoenle E, Zapf J, Hauri C, Steiner T, Froesch ER (1985) Comparison of in vivo effects of insulin-like growth factor I and II and of growth hormone in hypophysectomized rats. Acta Endocrinol 108: $167-174$

29. Zapf J, Walter H, Froesch ER (1981) Radioimmunological determination of insulinlike growth factor I and II in normal subjects and patients with growth disorders and extrapancreatic tumor hypoglycaemia. J Clin Invest 68: 1321-1330

30. Daughaday WH, Parker KA, Borowsky S, Trivedi B, Kapadia M (1982) Measurement of somatomedin-related peptides in fetal, neonatal and maternal rat serum by insulin-like growth factor (IGF) I radioimmunoassay, IGF-II radioreceptor assay (RRA), and multiplication-stimulating activity (MSA) after acid-ethanol extraction. Endocrinology 110:575-581

31. Yang YW-H, Wang J-F, Orlowski CC, Nisseley SP, Rechler MM (1989) Structure, specificity, and regulation of the insulin-like growth factor-binding proteins in adult rat serum. Endocrinology $125: 1540-1555$

Received: 26 March 1992

and in revised form: 9 June 1992

Dr. H. Hartmann

Medizinische Universitätsklinik

Robert-Koch-Strasse 40

W-3400 Goettingen

FRG 